\title{
Back to life: How to use positive psychology to beat anorexia?
}

Savukoski, Marika

Municipality of Pyhäranta, Finland (marika.savukoski@gmail.com)

Määttä, Kaarina $\$

University of Lapland, Finland (Kaarina.Maatta@ulapland.fi)

Uusiautti, Satu

University of Lapland, Finland (satu@uusiautti.fi)

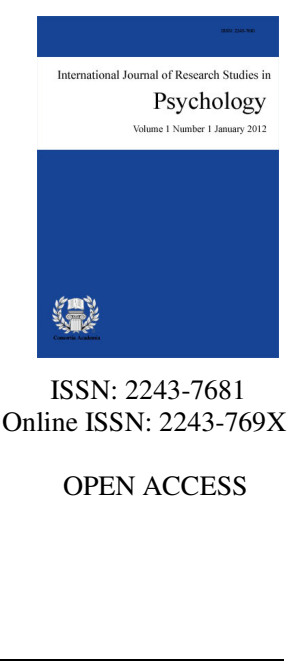

Received: 9 October 2011

\section{Abstract}

The aim of this research is to study the enigma of anorexia nervosa, and its survival from a positive point of view. The subjects are Finnish ex-anorectic women $(\mathrm{N}=11)$, between the ages of 23 and 45 years. The focus of this article is to describe and discuss the features and factors that made survival possible and to consider the actual process that led to survival. Furthermore, the attention is drawn to positive coping strategies and the present article is based on positive psychology. The study offers hope to everyone who struggles with this difficult disease and their loved ones, friends, teachers, and healthcare professionals.

Keywords: eating disorder; anorexia nervosa; survival; positive psychology; narrative research 


\section{Back to life: How to use positive psychology to beat anorexia?}

\section{Introduction}

Anorexia nervosa is mostly related to different obsessions, an infinite desire to lose weight, and a huge fear of weight gain. Anorectic life seems to just rotate around food and dieting. The secret goal is to destroy one's own appetite completely (Miller \& Golden, 2010). Life is controlled and over-regulated; repeating the same routines day after day because of the fear of losing control. The anorectic believe that the control shows discipline and self-mastery (Bissada et al., 2008). In their own eyes, only slenderness and a body without fat appear to validate and offer a decent life (Bordo, 1993; Mussell, Mitchell, \& Binford, 2001; Schooler, 2008). Anorexia is a business deal grounded in hard thoughts, feelings, and fears, through self punishment (Puuronen, 2004a). Giddens (1996) describes anorexia as a form of addiction in late modern time. He lists the addictions in the anorectic as including coffee, drugs, alcohol, work, fitness, sex, and love. Anorexia demonstrates the negative effect of an individual in society (Giddens, 1996): anorexia enables individuals to try to resolve the question of how to be a good citizen in the performance and efficiency of a society that values them (Michel \& Willard, 2003).

An estimated 5-10 million girls and women, and nearly a million boys and men, suffer from some form of eating disorder (Michel \& Willard, 2003). In Finland, about two percent of women aged between 15 and 20 develop eating disorders and 15 percent have problems with eating (Ruuska, 2006). It is one of the most common problems for young women with mental health disorders (Yager et al., 2005). In the last decade, according to some research, only about half of the sufferers recover from anorexia (Zandian, Ioakimidis, Bergh, \& Söderman, 2007; Seller \& Ravalia, 2003) while in a recent Finnish study, two thirds showed improvement in five years (Keski-Rahkonen et al., 2007). Some previous studies focusing on beating eating disorders have been conducted (e.g. Lindblad, Lindberg, \& Hjern, 2006; Wagner et al., 2007; Weawer, Wuest, \& Ciliska, 2005) but still survival is not guaranteed or the results appear inconsistent (Bulik, 2002; Sullivan, 2003).

The present research gives an extraordinary and unique sight into forms of eating disorders, anorexia, and the enigma of illness and survival from it. The article is based on the interviews of 11 ex-anorectic subjects who each gave their story about their anorectic trip experience and survival. Because of the importance of survival, this research is based on positive psychology as peculiar as it may sound. What could positive psychology offer for the discussion concerning eating disorders, such as anorexia? Anorexia is a serious condition that has to be treated properly - yet the focus of positive psychology is on people's well-being and positive behavioral styles. However, our assumption here is that by paying more attention to the survival stories and the phenomenon of conquering anorexia, we could contribute a positive viewpoint that could help the anorectic and their love ones to struggle and live down anorexia (Swanson et al., 2011). The article gives hope and strength to believe in healthier tomorrow both to anorectics and their loved ones (e.g. Sim et al., 2010). Therefore, one purpose of the article is to provide the means to survive without losing sight of the difficult fight against anorexia or the painful experiences.

\section{Theoretical framework}

\subsection{Anorexia and Health}

There are several significant typical characteristics of anorexia (Attia \& Walsh, 2007). The American Psychiatric Association published by definition (DSM-IV) in 1987 the following types:

$>$ A person loses weight to such an extent that their weight drops to at least 15 percent below normal weight. 
$>$ There is a personal fear of weight gain and obesity despite the fact that they are already underweight.

$>$ A person considers himself/herself fat although being already abnormally thin.

> Women have amenorrhea and menstruation "opt-out".

Other distinguishing features of anorexia nervosa are hair loss, reduced body temperature, continuous feeling of cold, poor circulation, dry skin, insomnia, nail brittleness, excessive interest in food and calories, low self-esteem, isolation, loneliness, and the inability to concentrate on anything except weight reduction (Bryant-Waugh, 2006; Duker \& Slade, 2003). A person diagnosed with anorexia nervosa is classified as having a BMI (Body Mass Index $=$ weight divided by height squared) of less than 17.5 (Abraham \& Llewellyn-Jones, 2001).

Anorexia is often initiated in adolescence and triggered by new situations in life (Engblom, 1998; Swanson et al., 2011). Impetus for anorexia can come from the simple fear of adolescence. Young people would like to remain young and youthful; avoiding adulthood which brings the inevitable necessity of maturity with menstruation and responsibilities (Charpentier, 1998; Lawson et al., 2007). Young people live in the middle of turbulence and seek identity and a place in the world and they have to face their own sexuality and vulnerability (Jaffe \& Worobey, 2006). As this kind of crisis develop and make the young feel helpless, they may response to the challenges of society by beginning to destroy themselves through anorexia.

Anorexia is the most extreme response. Becoming anorectic is a form of direction where one turns away from oneself and pursues model citizenship or even something bigger. Anorexia is not comparable with catching a flu and anorectic behavior often starts with sincere aims and commitment to make things right. Their main purpose is to keep transforming into a better person which is thought of being reachable by developing anorexia (e.g. Hurley \& Taber, 2008). The change does not always imply a deliberate action but it includes anorectic experiences that provide a better situation than the one in the past (Puuronen, 2004a; Puuronen, 2004b). Maffesoli (1995) sees the cure in the adoption of self-turning and self-rescue. Developing anorexia is a sort of call to draw attention to one self and an anorectic person carefully and constantly analyzes the question whether he/she lives sufficiently healthy life, whether his/her weight stays within the limits for an ideal body mass index, and whether he/she is successful in life. Becoming anorectic is a self-absorbed way of living and which - seen through other people's eyes_-appears as a very selfish activity (Puuronen, 2004b; Michel \& Willard, 2003).

Anorexia can be regarded as the "caricatures" of the events that occur when a general recommendation for losing weight is taken too literally and run into the ground. Normal diet becomes scarce and foods, which the anorectic accept, are too healthy (e.g. Muller, 2009). The anorectic will remove fat from the diet followed by products containing sugar and this will continue until the only products left are those one containing energy close to zero. Hunger is the maximum enjoyment of the day while eating is such a frightening and distressing experience that persons with anorexia no longer want to be visible to others at the dinner table at the same time (Lucas, 2004; Thurfjell, 2005). Persons with anorexia are unwavering with self-discipline; they are masterful in their eating anxiety when it comes to limiting and not even wanting to taste the "damaging", forbidden food. They are afraid of losing control of themselves if they eat - and therefore, they decide not to eat (Bissada, Tasca, Barber, \& Bradwejn, 2008; Bordo, 1993). Eating whatever, however, and at any time is impossible for the anorectic because it violates their "rules" (Puuronen, 2004b). Still, cooking for others is wonderful because the anorectic enjoy watching others eat. The anorectic collect recipes and walk around the shops to admire the forbidden fruit - the shelves full of delicacies which they do not have the right to consume (Lucas, 2004). In addition, there are plenty of studies that have analyzed the connection between anorexia and suicides and mortality (Bulik et al., 2008; Kaye, 2009; Papadopoulos, Ekbom, Brandt, \& Ekselius, 2009).

\subsection{Positive Psychology Provides a Positive Attitude toward Life}

Interest in themes such as well-being, happiness, quality of life, and positive feelings is germane to positive psychology, a field that has offered studies into the positive characteristics, feelings and strengths of individuals 
and has also sought to identify phenomena that promote and enhance such positive attributes (Seligman et al., 2005; Aspinwall \& Staudinger, 2003). Gable and Haidt (2005) briefly define positive psychology in the following terms: "Positive psychology is the study of the conditions and processes that contribute to the flourishing or optimal functioning of people, groups, and institutions" (Gable \& Haidt, 2005).

The research on the life-span has also contributed to the systematic research on accomplishments and success (Aspinwall \& Staudinger, 2003). The research on happiness has taken root increasingly: in order to know why some people are happier - regardless of the setbacks - than others, we have to understand what the cognitive and motivational processes are that maintain and even increase the happiness and positive attitude (Lyubomirsky, 2001). If surviving from anorexia is dissected from a positive perspective, this view is also of great interest. Positive feelings support problem-solving skills and the ability to act in a proactive way. The full importance and potential of this may seem surprising as the emotion of happiness is so simple and common in nature (Isen, 2006). Positive psychology is also interested in the life spans of positively behaving people and what factors play a key role during the life spans of strong and optimistic people, and how could these factors be recognized? These questions are essential when researching the experiences of beating anorexia.

Well-being is comprehensive social, physical, and emotional experience. It can also be dissected from the point of view of individual strengths that are at the core of positive psychology (Aspinwall \& Staudinger, 2003; Carruthers \& Hood, 2005) and the focus on human strengths brings positive aspect into well-being and life in general. Seligman and Peterson (2003) have analyzed human strengths and how individuals have the possibility to achieve positivity in various life situations. Open mind, critical thinking, and courage, caring for other people, justice, self-regulation, optimism, and hope, among other things, are strengths with which people can achieve well-being (Seligman et al., 2005; Carver \& Scheier, 2002) and should be exploited when struggling with anorexia as well. Therefore, supporting human strengths can enhance, for its part, coping with difficult life situations and events, such as anorexia.

\section{Research Method, Data and Analysis}

\subsection{Research Questions}

In this article, our purpose is to dissect the survival stories of those persons who have beaten anorexia: the first and foremost aim is to bring out the factors which made it possible to break free from the anorectic trip. For this reason, one focus of this article is to describe the actual process and models leading to survival. The following question will be answered: What kind of experiences does the process of recovering from anorexia consist of?

The results are considered from the positive point of view. Based on the results, the thought of employing positive psychology in recovering from anorexia will be discussed at the end of the article.

\subsection{Data and Methods}

The aim of this research is to understand the reality of anorectic life and related experiences through the individuals' perspective. Those who did get ill are the real experts in describing how they survived. The goal of narrative research is to give subjects the opportunity to make their voices heard because the information which is formed in this way is more polyphonic and varied (e.g. Holloway, 2011). In this research, participants were Finnish ex-anorectic women ( $\mathrm{N}=11)$ between the age of 23 and 45 years. They had developed anorexia when between 10 and 18 years old. Each participant's survival story describes their own view of their suffering, disappointments, successes, and joys.

The research participants were selected in this research mostly based on their own willingness to participate. The Finnish Anorexia Association (SYLI) helped in finding the research participants as the first author of this 
article participates in the action of the association: it informed through its channels of the possibility to participate in this research. Six participants were reached this way. The interviews were designed to concentrate on the interviewees' narration.

Narrative is often associated with the constructivist view of information; reference to the nature of knowledge, knowing, and the process of knowledge itself. In this study, narrative refers mainly to the nature of the research material and the research data analysis but, equally, it is also research with a constructivist view of knowledge because the examinees themselves have built their knowledge and reality through social interaction (Lieblich, Tuval-Mashiach, \& Zilber, 1998; Garro \& Mattingly, 2000; Mahoney, 2002). Silverman (2005) points out that research subjects and research tasks for each study are the keys to selecting the most appropriate data collection method. The method in question in this research resembles an application of self-assessment that has been utilized and its reliability has been evaluated in previous researches on anorexia widely (e.g. Ratner \& Rumbold, 1994; Schoemaker, van Strien, \& van der Staak, 1994). In this study, the method selected was oral data collection in which the narratives are collected by interviews. In addition, data also consisted of written narratives. The purpose of this study is to describe the participants' survival from anorexia through narratives which have emerged from their personal experiences.

Narrative is also reflected in the method of data analysis which, in this study, was carried out by narrative analysis. In addition, the analysis was also used for categorical content analysis (See Lieblich, Tuval-Machiach, \& Zilber, 1998; Polkinghorne, 1995). Certainly the generalizability, validity, and reliability of the results can be criticized. How truthful are these narratives? They are stories that people who have developed anorexia and beaten it have wanted to bring out afterwards. They represent the truth that the participants have told about their own life. The narratives, thus, include the participants' interpretation of their experiences and they have either consciously or unconsciously withheld some of the experiences, while some other experiences are forgotten and some others are highlighted. Human memory is selective-nor were the participants even able to put everything into words (Buchbinder, 2011). However, those narratives that they have told voluntarily involve valuable information as such and form a reality of their own (Whittemore, Chase, \& Mandle, 2001; Wuest, 2011).

\section{Results}

Recovering from anorexia can be viewed as a development conversion during which persons with anorexia begin to observe the world around them in new ways making anorexia gradually disappear. The process is slow because they will have to re-learn the so-called normal life. Healing should involve long-term projects of experimental and internal discovery during which it is acceptable to fail and grope towards success (Sim et al., 2010). It is important to remember that the way to a flat stomach is through a swollen belly and that the healing process, caused by anxiety and the presence of evil, comes after the freedom that allows the head to shatter the twisted thoughts and myths (Ster, 2006).

"Survival, it's like learning to read, because you have to be extremely careful in all the phases and steps not to fall apart, and then you had to slowly and carefully think over all the things: to cram, repeat, and practice. You had to feed information into yourself and those new schemes of things..."

When talking about their survival, the participants emphasized their spiritual survival stories and their analyzing methods - the processes through which each became anorectic or mindful of their initial experiences and feelings. These social supports aimed at finding the ways of coping with the emotional state and providing the ultimate aim of reducing the internal stress caused by emotional discomfort (Hogh \& Doftadottir, 2001).

"I had to learn that if someone feels bad it is not necessarily my fault at all. Or if someone has done wrong, I don't have to go and fix it immediately. I learned that you have a right to feel things and you don't have to hide them but, you know, to accept them." 
In practice, a known key to the survival is trying to work on negative emotions such as hatred, anger, and bitterness as well as learning about the lives of others who have had such feelings. Equally, it is a question of forgetting, forgiving, and finding meaning in their painful experiences (Lazarus \& Folkman, 1984; Endler \& Parker, 1994). The extent of an individual's internal stress-regulatory refers mainly to the abilities of elimination, problem solving, emotional processing, and partly also the control of the above mentioned. When beating anorexia, persons with anorexia are not able to change their life but they have to change themselves. Giddens (1991) calls this approach to anorectic survival the idea of an identity project during which the persons with anorexia are reflective and re-evaluate them in order to continue efforts for survival. Yet, it is important to allow time for setbacks and occasional returns to anorectic life as the healing is not always - if ever - straightforward.

"For me, survival is more like becoming harmonious, like sewing the wounds and fixing the scarves engraved in your mind; those scarves that had been opened by all the comments, twitting, and insults. I learned to think from a whole new perspective and tried to see myself in a whole new light, too."

The key to struggling against anorexia seems to be emphasizing the practical means to influence the situation or the ways to get help for oneself. Lazarus and Folkman (1984) tested these problem-based methods along with Endler and Parker (1994) for task-oriented survival. These methods of testing included enrollment in public health care, school health care, or peer groups. Sports, hobbies, and sometimes the use of pharmaceuticals proved to be successful in solving problems (Latack \& Havlovic, 1992, see also Jackson, Cates, \& Lorenz, 2010; Muller, 2009: Rossi et al., 2007).

\section{"It relieved me in a big way. I could talk the monster out of my head; and that psychologist who luckily happened to be a great person was the most helpful. Namely, I have heard afterwards that quite many, equal to me, have had really bad experiences on the psychologists and their ways of action..." \\ "There [at yoga] I became acquainted with my own body and its needs. And that put my mind at rest too... Since, I have done some jogging and swimming as well but that yoga has become a permanent hobby for me."}

Beating anorexia appears to be driven by both the spiritual survival of the process, whose main objective is to reach and overcome the emotions caused by the anorectic experiences and by learning to live with these feelings. It also involves practical problem solving means such as seeking outside assistance (Latack \& Havlovic, 1992). However, it also affects survival attitudes in the physical environment and the challenges of everyday living including how a person may combine work, study, and family life. It is important to note that the survival in each case may be very different for different individuals. A person may feel that a particular way of survival is good and meaningful while the method employed could be seen by outsiders as redundant and inefficient (Vitaliano et al., 1990). Therefore, the evaluation of the effectiveness of survival is not in priority since an individual's own experience of survival is more important: whether the decisive step is in an active role of changing the situation or a passive one such as treatment (Lazarus \& Folkman, 1984; Rajala, 2001).

In this research, the aim was to find out what coping factors helped the persons with anorexia to find what is missing in their lives or how they survived as winners against the tough opponent of anorexia. There is more than one reason for developing anorexia and the same can be said about survival. Coping, for an individual, is the sum of several factors including the available resources, their strengths, previous life history, social status, and personality. This research, therefore, is just the beginning and adds another voice to those authors who have broken through the strong and protective wall which surrounds anorexia.

In this research the survivors had clear similarities which were repeated in almost every survival story. One such similarity was toughness - a characteristic perceived as striving in spite of adversity until the goal is reached. Persistence is also linked to a commitment and confidence in the target being achievable (Carver \& 
Scheier, 2003). According to Eisenberg and Wang (2003), the persistence of people is also able to help regulate their own behavior ranges which increases the persistent human adaptability, holistic well-being, and functioning. The survivors in this research proved to be persistent: at first they changed their lives very systematically, without giving up, toward a complete state of anorexia and then, later, they used that same tenacity to return back to a somewhat normal life. The disease, therefore, already demonstrated that the participants were tenacious when faced with a goal and but even more perseverant by surviving the many uphill battles faced after a long healing process.

“...but then I was thinking it over for a long time; that now the case is that I can't do this darn thinking any longer, that it is now or never: Either I decide that I will die or then I carry on living and actually do something. So then, I decided that I still want to live and get better really..."

Starting over was clearly one similar feature among the participants. It was reflected, above all, in the wider opportunities which invaded and changed their old, anorectic thoughts and eating habits by setting up small safety lines for a new life. Survival was also reflected in the changing of relationships, changes in the place of residence, relaxation of self-discipline, and also learning how to use relaxation and laziness. Putting things aside was a necessary strategy; a case of throwing overboard the whole anorectic life and taking up almost everything from scratch.

“...I really started to think about what I actually think of this and that, whether I want to go there, what kinds of people I like, and, you know, about all ordinary things. I think that all started from zero; I am ashamed to tell that I had to learn again how to brush my teeth, because at that time, I was so depressed that I couldn't do things like that."

On the other hand, the survivors needed time to manage both the journey and the trade-offs as carefully as possible. They needed the space and time to grow as well as the opportunity to develop and build their own identity in the imperfect world. Wenger (2002) mentioned the idea of the individual's inner dialogue about becoming and avoiding something. The persons with anorexia would construct their identities during coping or through social relations and by using various entities such as peer support groups (Wenger, 2002; Mahoney, 2002). Recovering from anorexia nervosa represents, therefore, a kind of growth. It requires maturation of ideas and comprehensive self-acceptance, mostly in adult life, as they have often developed anorexia already during a developmental crisis in their adolescence. Growth is also linked to improved self-esteem which is shown, above all, in self-respect and the success of social relationships (Mäkikangas, 2007).

"In my opinion, the conversation itself with those who had experienced the same is really a good thing. If you explained these things to someone who hasn't experienced it, it would be almost the same as talking to walls... When you have a talk with someone with the same experiences, it feels wonderful when you don't need to explain what you mean if you said aloud that 'darn how distressed I am'."

Beating anorexia is comparable with the idea of surviving and one of the desired outcomes is to achieve good life-management skills. The road to good life management consists of efforts to focus on causes, deploy information and advice, find a positive attitude to life, and make the use of already existing or newly-born internal strengths consciously. By using the strength of the classification developed by Fernández-Ballesteros (2003), the key survival factors among the participants in this research were optimism, internal motivation, personality development, social network and support, social opportunities, and partly confidence in aptitude, wisdom and happiness (see also Kaye, 2009).

Optimism was reflected in all of these examined factors as well as the courage to turn away from the familiar and safe in order to seize new life challenges (Folkman et al., 1986). Internal motivation resembled the participants' personal desire to survive and achieve sustainable improvements in life. Internal motivation 
describes, therefore, an individual's need to learn and develop but it also contains one's personality structure and motivation to develop (Nurmi \& Salmela-Aro, 2006; Ryan \& Deci, 2000). The subjects had self-realization which opened the way to turn from anorectic thoughts and provided the opportunity to enjoy a life of sport, art, animals, or music. Social support was considered an opportunity to talk about the difficulties and contradictions with someone else but also a channel to get new information about the problem. Furthermore, social support enabled the anorectic to request assistance and experience the feeling of security (Keski-Rahkonen et al., 2007; Scheff, 1990.) Social contacts opened up opportunities to visualize a normal life and reflect on distorted perceptions.

\begin{abstract}
"She [a friend] has been able to be by my side the whole time and when I was in a bad shape, she would be in contact with me all the time and ask how I am doing. She also understands me in that sense well, because she has had the same kinds of experiences; however, just a little bit different situation than mine is. You know, we can understand each other more easily and we don't face a situation where one would consider the other stupid after acting in some insane way ever. Both understand that this action might not be conscious but there is a reason for it."
\end{abstract}

Happiness was revealed and, above all, when acquired through the love of either a spouse or a child created the power to remain and survive. True love, which was based on happiness, gave the participants an opportunity to grow as a person and meet their goals (Hendricks \& Hendricks, 2002). Self-examination awoke confidence through both the ability and the crucial experience of surviving an attainable goal. Maddux (2002) notes that personal faith in achieving the goal is one of the most important factors that lead to success. All of these strengths are basic wisdom and reflect the internal resources examined and detected in the study for the adjustment of life's tensions and seeing the puzzle piece by piece (Baltes \& Freund, 2003).

“..I still don't know why I didn't die from these medications. Neither could anyone else explain it to me. I have been thinking myself that it wasn't my time to go yet and this information gave me a lot of strength... Therefore, in the middle of feeling so powerful, there in the hospital, I decided that I will end anorexia, not myself..."

\title{
5. Conclusions and Discussion
}

People who have beaten anorexia find it often difficult to name the exact factors that have brought them toward survival (e.g. Bulik, 2002; Lindblad, Lindberg, \& Hjern, 2006; Sullivan, 2003; Wagner et al., 2007; Weaver, Wuest, \& Ciliska, 2005). Anorectic time consists of painful memories; which is good because, otherwise, the continuation of life would be really difficult. However, it also makes the survival difficult as some experiences can be completely ignored and concealed. The coping factors which were found in this research may somehow generate understanding about those types through which survival is possible and these results are mostly exemplary approaches to anorexia. Furthermore, based on the results, we encourage people who help the persons with anorexia to take into account the individual's life as a whole rather than offering them a pre-packed, particular or existing model of treatment. Thus, recovering from anorexia cannot be described through any particular model or strategy because the underlying models of individuals facing the coping task meet many twists, turns, or pauses. After all, survival consists of good luck and happiness as well as being aware of different coping models through which the motivation to survive will be aroused.

Recovering anorexia seems to be both art and science: Science in the sense that the persons with anorexia have invented ways to deal with the state of malnutrition and art in the sense that any treatment depends of the situation, personality, and experience and is unique. Large, ad hoc approaches, due to differences in treatments, are not for everyone (Lucas, 2004) and predicting the result can be difficult because patients do not want treatment. Particularly difficult and long-lasting therapy will often go hand in hand with other problems such as obsessive and compulsive disorder, anxiety disorder, personality disorder, major depressive disorder, massive fatigue, confusion, thoughts of suicide, family problems, alcohol, drugs, and medicine abuse (Lock et al., 2010; 
McIntosh et al., 2005; Seller \& Ravalia, 2003). Recovering from anorexia nervosa is not a miracle but mostly a long, unpleasant, and complicated journey toward an internal and external transformation. Treatments are extremely important forms of support and security to persons with anorexia who are directed in a new journey (see also Savukoski, Määttä, \& Uusiautti, 2011).

In this article, we wanted to pay special attention to the positive approach of beating anorexia. It was possible through the participants' survival stories as the aim was to bring out positive elements that help struggling with anorexia and that could be of use both for persons with anorexia and their loved ones. Focusing on personal strengths and finding the positive attitude toward the change away from the anorectic life and - the most importantly - toward oneself, appeared difficult but crucial means to survival. In counseling and psychotherapy and clinical psychology, applied positive psychology builds on the traditions of humanistic psychology and promotes a dimensional understanding of mental health and mental illness by, for example, contributing happiness-increase interventions, such as using signature strengths, person-centered approach and positive therapy, and life coaching (Linley et al., 2009). At the subjective level, positive psychology concentrates on subjective experiences, well-being, satisfaction, flow, joy, pleasure, and happiness, as well as on optimistic and hopeful attitude and confidence in the future. At the group level, the interest is on the civil skills and institutions that make the individuals turn into better citizens - responsible, flexible, and ethical people (Seligman, 2002.) In future, it would be interesting to conduct interventions that are based on positive psychology and at the institutional level to analyze how anorexia could be prevented or how its treatment could be enhanced by functional and health-promoting institutions.

\section{References:}

Abraham, S., \& Llewellyn-Jones, D. (2001). Eating disorders. The facts. Oxford: Oxford University Press. Aspinwall, L. G., \& Staudinger, U. M. (Eds.) (2003). A psychology of human strengths: Fundamental questions and future directions for a positive psychology. San Francisco, CA: Berrett-Koehler.

Attia, E., \& Walsh, B. T. (2007). Anorexia Nervosa. The American Journal of Psychiatry, 164(12), 1805-1810. $<$ http://dx.doi.org/10.1176/appi.ajp.2007.07071151>

Baltes, P. B., \& Freund, A. M. (2003). Human strengths as the orchestrations of wisdom and selective optimization with compensation. In L. G. Aspinwall \& U. M. Staudinger (Eds.), A psychology of human strengths: Fundamental questions and future directions for a positive psychology (pp. 23-35). San Francisco, CA: Berrett-Koehler. <http://dx.doi.org/10.1037/10566-002>

Bissada, H., Tasca, G. A., Marber, A. M., \& Bradwejn, J. (2008). Olanzapine in the treatment of low body weight and obsessive thinking in women with anorexia nervosa: a randomized, double-blind, placebo-contolled trial. The American Journal of Psychiatry, 165(10), 1281-1288. <http://dx.doi.org/10.1176/appi.ajp.2008.07121900>

Bordo, S. (1993). Unbearable weight. Feminism, western culture and body. Berkeley, CA: University of California Press.

Bryant-Waugh, R. (2006). Recent developments in Anorexia Nervosa. Child and Adolescent Mental Health, 11(2), 76-81. <http://dx.doi.org/10.1111/j.1475-3588.2005.00388.x>

Buchbinder, E. (2011). Beyond checking. Experiences of the validation interview. Qualitative Social Work, 10(1), 106-122. <http://dx.doi.org/10.1177/1473325010370189>

Bulik, C. M. (2002). One half of patients with anorexia nervosa fully recovered after 21 years but the other half had a chronic or lethal course. Evidence Based Mental Health, 5(2), 59. $<$ http://dx.doi.org/10.1136/ebmh.5.2.59>

Bulik, C. M., Thornton, L., Poyastro Pinheiro, A., Kaye, W. H. (2008). Suicide attempts in Anorexia Nervosa. Psychosomatic Medicine, 70(3), 378-383. <http://dx.doi.org/10.1097/PSY.0b013e3181646765>

Carruthers, C., \& Hood, C. D. (2005). The power of positive psychology. Parks \& Recreation, Oct 2005, 30-37.

Carver, C. S., \& Scheier, M. F. (2002). Optimism. In C. R. Snyder \& S. J. Lopez (Eds.), Handbook of positive psychology (pp. 231-243). Oxford: Oxford University Press. 
Savukoski, M., Määttä, K., \& Uusiautti, S.

Carver, C. S., \& Scheier, M. F. (2003). Three human strengths. In L. G. Aspinwall \& U. M. Staudinger (Eds.), A psychology of human strengths: Fundamental questions and future directions for a positive psychology (pp. 87-102). San Francisco, CA: Berrett-Koehler. <http://dx.doi.org/10.1037/10566-007>

Charpentier, P. (1998). Anoreksia ja bulimia [In Finnish]. [Anorexia and Bulimia]. In P. Charpentier (Ed.), Nuorten syömishäiriöt ja lihavuus. [Young people's eating disorders and obesity] (pp. 7-24). Jyväskylä: Kirjapaino Oma.

Duker, M., \& Slade, R. (2003). Anorexia Nervosa and Bulimia. How to help. Buckingham: Open University Press.

Eisenberg, N., \& Wang, V. O. (2003). Toward a positive psychology: Social developmental and cultural contributions. In L. G. Aspinwall \& U. M. Staudinger (Eds.), A psychology of human strengths: Fundamental questions and future directions for a positive psychology (pp. 117-129). San Francisco, CA: Berrett-Koehler. <http://dx.doi.org/10.1037/10566-009>

Endler, N. S., \& Parker, J. D. A. (1994). Assessment of multidimensional coping: task, emotion and avoidance strategies. Psychological Assessment, 6(1), 50-60. <http://dx.doi.org/10.1037/1040-3590.6.1.50>

Engblom, P. (1998). Naisen itsekokemus, identiteetti ja psykodynaaminen psykoterapia syömishäiriöissä [In Finnish] [Woman's experience of self, identity and psychodynamic psychotherapy in eating disorders]. Helsinki: Hakapaino.

Fernández-Ballesteros, R. (2003). Light and dark in the psychology of human strengths: The example of psychogerontology. In L. G. Aspinwall \& U. M. Staudinger (Eds.), A psychology of human strengths: Fundamental questions and future directions for a positive psychology (pp. 131-147). San Francisco, CA: Berrett-Koehler. <http://dx.doi.org/10.1037/10566-010>

Folkman, S., Lazarus, R. S., Dunkel-Schetter, C., DeLongis, A., \& Gruen, R. J. (1986). Dynamics of a stressful encounter outcomes. Journal of Personality and Social Psychology, 50(5), 992-1003. $<$ http://dx.doi.org/10.1037/0022-3514.50.5.992>

Gable, S., \& Haidt, J. (2005). What (and why) is positive psychology? Review of General Psychology, 9, 103-110. <http://dx.doi.org/10.1037/1089-2680.9.2.103>

Garro, C., \& Mattingly, L. C. (2000). Narrative and the cultural construction of illness and healing. Berkeley, CA: University of California Press.

Giddens, A. (1991). Modernity and self-identity. Self and society in the late modern age. Cambridge: Polity Press.

Giddens, A. (1996). Life in post-traditional society. In U. Beck, A. Giddens, \& S. Lash (Eds.), Modern track. Reflexive modernization (pp. 83-152). Cambridge: Polity Press.

Hendricks, S., \& Hendricks, C. (2002). Love. In C. R. Snyder \& S. J. Lopez (Eds.), Handbook of positive psychology (pp. 472-484). Oxford: Oxford University Press.

Hogh, A., \& Dofradottir, A. (2001). Coping with bullying in the workplace. European Journal of Work and Organizational Psychology, 10(4), 485-495. <http://dx.doi.org/10.1080/13594320143000825>

Holloway, I. (2011). Being a qualitative researcher. Qualitative Health Research, 21(7), 968-975. $<$ http://dx.doi.org/10.1177/1049732310395607 >

Hurley, R. A., \& Taber, K. H. (2008). Imaging of eating disorders: multiple techniques to demonstrate the dynamic brain. The Journal of Neuropsychiatry and Clinical Neurosciences, 20(3), iv-260. $<$ http://dx.doi.org/10.1176/appi.neuropsych.20.3.iv>

Isen, A. M. (2006). Myönteinen tunne ihmisen vahvuuden lähteenä [In Finnish] [Positive feeling as a source of human strength]. In L. G. Aspinwall \& U. M. Staudinger (Eds.), Ihmisen vahvuuksien psykologia [The psychology of human strengths] (pp. 186-201). Helsinki: Edita.

Jackson, C. W., Cates, M., \& Lorenz, R. (2010). Pharmacotherapy of eating disorders. Nutrition in Clinical Practice, 25(2), 143-159. <http://dx.doi.org/10.1177/0884533610362239>

Jaffe, K., \& Worobey, J. (2006). Mothers' attitudes toward fat, weight and dieting in themselves and their children. Body Image, 3(2), 113-120. <http://dx.doi.org/10.1016/j.bodyim.2006.03.003>

Jakobsen, M., \& Wiegand, E. (1996). Muutosvoima minussa. Nuoren selviytyminen arkielämän paineissa ja kriisitilanteissa. [Change in power within me. Coping with the young in the pressures of everyday life 
and in times of crisis]. Jyväskylä: Gummerus.

Kaye, W. (2009). Eating disorders: hope despite mortal risk. The American Journal of Psychiatry, 166(12), 1309-1311. <http://dx.doi.org/10.1176/appi.ajp.2009.09101424>

Keski-Rahkonen, A., Hoek, H. W., Susser, E. S., \& Rissanen, A. (2007). Epidemiology and course of anorexia nervosa in the community. American Journal of Psychiatry, 164(8), 1259-1265. $<$ http://dx.doi.org/10.1176/appi.ajp.2007.06081388>

Latack, J. C., \& Havlovic, S. J. (1992). A conceptual evaluation framework for coping measures. Journal of Organizational Behavior, 13(5), 479-508. <http://dx.doi.org/10.1002/job.4030130505>

Lawson, E. A., Miller, K. K., Mathur, V. A., Misra, M., Meenaghan, E., Herzog, D. B., \& Klibanski, A. (2007). Hormonal and nutritional effects on cardiovascular risk markers in young women. The Journal of Clinical Endocrinology \& Metabolism, 92(8), 3089-3094. <http://dx.doi.org/10.1210/jc.2007-0364>

Lazarus, R. S., \& Folkman, S. (1984). Stress, appraisal and coping. New York, NY: Springer.

Lieberman, S. (1995). Anorexia Nervosa: the tyranny of appearances. Journal of Family Therapy, 17(1), 133-138. $<$ http://dx.doi.org/10.1111/j.1467-6427.1995.tb00008.x>

Lieblich, A., Tuval-Machiach, R., \& Zilber, T. (1998). Narrative research: Reading, analysis and interpretation. Thousand Oaks, CA: Sage.

Lindblad, F., Lindberg, L., \& Hjern, A. (2006). Improved survival in adolescent patients with anorexia nervosa: a comparison of two Swedish national cohorts of female inpatients. The American Journal of Psychiatry, 163(8), 1433-1435. <http://dx.doi.org/10.1176/appi.ajp.163.8.1433>

Linley, P. A., Joseph, S., Maltby, J., Harrington, S., \& Wood, A. M. (2009). Positive psychology applications. In S. J. Lopez \& C. R. Snyder (Eds.), Oxford handbook of positive psychology (pp. 35-47). Oxford: Oxford University Press,

Lock, J., et al. (2010). Randomized clinical trial comparing family-based treatment with adolescent-focused individual therapy for adolescents with anorexia nervosa. Archives of General Psychiatry, 67(10), 1025-1032. <http://dx.doi.org/10.1001/archgenpsychiatry.2010.128>

Lucas, A. R. (2004). Demystifying anorexia nervosa: an optimistic guide to understanding and healing. Oxford: Oxford University Press.

Lyubomirsky, S. (2001). Why are some people happier than others? The role of cognitive and motivational processes in well-being. American Psychologist, 56, 239-249. $<$ http://dx.doi.org/10.1037/0003-066X.56.3.239>

Maddux, J. E. (2002). Self-Efficacy. The power of believing you can. In C. R. Snyder \& S. J. Lopez (Eds.), Handbook of Positive Psychology (pp. 277-287). Oxford: Oxford University Press.

Maffesoli, M. (1995). Maailman mieli: yhteisöllisen tyylin muodoista [In Finnish] [The world's mind: collaborative style formats]. Helsinki: Gaudeamus.

Mahoney, M. J. (2002). Constructivism and positive psychology. In C. R. Snyder \& S. J. Lopez (Eds.), Handbook of positive psychology (pp. 745-750). Oxford: University Press.

McIntosh, V. V. W. (2005). Three psychoterapies for anorexia nervosa: a randomized, controlled trial. The American Journal of Psychiatry, 162(4), 741-747. <http://dx.doi.org/10.1176/appi.ajp.162.4.741>

Michel, D. M., \& Willard, S. G. (2003). When dieting becomes dangerous. A guide to understanding and treating anorexia and bulimia. Yale: Yale University Press.

Miller, C. A., \& Golden N. H. (2010). An introduction to eating disorders: clinical presentation, epidemiology, and prognosis. Nutrition in Clinical Practice, 25(2), 110-115.

$<$ http://dx.doi.org/10.1177/0884533609357566>

Muller, W. (2009). Towards research-based approaches for solving body composition problems in sports: ski jumping as a heuristic example. British Journal of Sports Medicine, 43(13), 1013-1019. <http://dx.doi.org/10.1136/bjsm.2009.068775>

Mussell, P. M., Mitchell, J. E., \& Binford, R. B. (2001). Anorexia Nervosa. In J. E. Mitchell (Ed.), Outpatient treatment of eating disorder: a guide for therapist, dieticians and physicians (pp. 5-25). Minnesota: University of Minnesota Press.

Mäkikangas, A. (2007). Personality, well-being and job resources. From negative paradigm towards positive 
psychology. Jyväskylä: Jyväskylä University Printing House.

Nurmi, J.-E., \& Salmela-Aro, K. (2006). What works make you happy: the role of personal goals in life-span development. In M. Csikszentmihalyi \& I. S. Csikszentmihalyi (Eds.), Life worth living: contributions of positive psychology (pp. 182-199). Oxford: Oxford University Press.

Papadopoulos, F. C., Ekbom, L., Brandt, L., \& Ekselius, L. (2009). Excess mortality, causes of death and prognostic factors in anorexia nervosa. The British Journal of Psychiatry, 194(1), 10-17. <http://dx.doi.org/10.1192/bjp.bp.108.054742>

Polkinghorne, D. (1995). Narrative configuration in qualitative analysis. In J. A. Hatch \& R. Wisniewski (Eds.), Life history and narrative (pp. 5-24). London: Falmer.

Puuronen, A. (2004a). Rasvan tyttäret. Etnografinen tutkimus anorektisen kokemustiedon kulttuurisesta jäsentymisestä [In Finnish]. [Daughters of fat. Ethnographic research of anorectic knowledge gained from experience of cultural organization]. Helsinki: Hakapaino.

Puuronen, A (2004b). Anoreksia uskontotieteen tutkimuskentällä [In Finnish]. [Anorexia in the field of religion science]. In O. Fingerroos, M. Opas, \& T. Taira (Eds.), Uskonnon paikka. Kirjoituksia uskontojen ja uskontoteorioiden rajoista [Place of religion. Writings of the limits of religions and religious theories]. Helsinki: Hakapaino.

Rajala, R. (2001). Stressinhallinta opettajien kertomuksissa: onnistunut ja epäonnistunut stressinhallinta kouluyhteisössä [In Finnish] [Stress management teacher reports: successful and unsuccessful stress management in the school community]. Rovaniemi: University of Lapland.

Rathner, G., \& Rumpold, G. (2006). Convergent validity of the eating disorder inventory and the anorexia nervosa inventory for self-rating in an Austrian nonclinical population. International Journal of Eating Disorders, 16(4), 381-193. $<$ http://dx.doi.org/10.1002/1098-108X(199412)16:4<381::AID-EAT2260160407>3.0.CO;2-Q>

Rossi, G., Balottin, U., Rossi, M...\& Lanzi, G. (2007). Pharmacological treatment of anorexia nervosa: a retrospective study in preadolescents and adolescents. Clinical Pediatrics, 46(9), 806-811. $<$ http://dx.doi.org/10.1177/0009922807303929>

Ruuska, J. (2006). The impact of eating disorders on the adolescent process. Tampere: Tampere University Press.

Ryan, R. M., \& Deci, E. L. (2000). Self-determination theory and the facilitation of intrinsic motivation, social development and well-being. American Psychologist, 55(1), 68-78. $<$ http://dx.doi.org/10.1037/0003-066X.55.1.68>

Savukoski, M., Määttä, K., \& Uusiautti, S. (2011). The other side of well-being-what makes a young woman become an anorectic? International Journal of Psychological Studies, 3(2), 76-86. $<$ http://dx.doi.org/10.5539/ijps.v3n2p76>

Scheff, T. (1990). Microsociology. Discourse, emotion, and social structure. London: The University of Chicago Press.

Schoemaker, C., van Strien, T., \& van der Staak, C. (1994). Validation of the eating disorders inventory in a nonclinical population using transformed and untransformed responses. International Journal of Eating Disorders, 15(4), 387-393. <http://dx.doi.org/10.1002/eat.2260150409>

Schooler, D. (2008). Real women have curves: a longitudinal investigation of TV and the body image development of Latina adolescents. Journal of Adolescent Research, 23(2), 132-153. $<\underline{\text { http://dx.doi.org/10.1177/0743558407310712> }}$

Seligman, M. E. P. (2002). Positive psychology, positive prevention, and positive therapy. In C. R. Snyder \& S. J. Lopez (Eds.), Handbook of positive psychology (pp. 3-9). Oxford: Oxford University Press..

Seligman, M. E. P., \& Peterson, C. (2003). Positive clinical psychology. In L. Aspinwall \& U. Staudinger (Eds.), A Psychology of human strengths. Fundamental questions and future directions for a positive psychology (pp. 305-317). Washington, DC: American Psychological Association. $<$ http://dx.doi.org/10.1037/10566-021>

Seligman, M. E. P., Steen, T. A., Park, N., \& Peterson, C. (2005). Positive psychology progress. Empirical validation of interventions. American Psychologist, 60, 410-421. 
$<$ http://dx.doi.org/10.1037/0003-066X.60.5.410>

Seller, C. A., \& Ravalia, A. (2003). Anaesthetic implications of anorexia nervosa. Anesthetic, 58(5), 437-443. $<$ http://dx.doi.org/10.1046/j.1365-2044.2003.03130.x>

Silverman, D. (2005). Doing qualitative research. A practical handbook. (2nd ed.) London: Sage.

Sim, L. A., McAlpine, D. E., Grothe, K. B., \& Clark, M. M. (2010). Identification and treatment of eating disorders in the primary care setting. Mayo Clinic Proceedings, 85(8), 746-751. $<$ http://dx.doi.org/10.4065/mcp.2010.0070>

Ster, G. V. D. (2006). Lupa syödä. Opas syömishäiriöiden hoitoon [In Finnish]. [Licensed to eat. Guide to eating disorders treatment]. Helsinki: Edita Prima.

Sullivan, P. F. (2003). Discrepant results regarding long-term survival of patients with anorexia nervosa? Mayo Clinic Proceedings, 78(3), 273-274. <http://dx.doi.org/10.4065/78.3.273>

Swanson, S. A., Crow, S. J., Le Grange, D., Swendsen, J., \& Merikangas, K. R. (2011). Prevalence and correlates of eating disorders in adolescents: results from the national comorbidity survey replication adolescent supplement. Archive of General Psychiatry, 68(7), 714-723. $<$ http://dx.doi.org/10.1001/archgenpsychiatry.2011.22>

Thurfjell, B. (2005). Adolescent eating disorders in a socio-cultural context. Uppsala: Uppsala University.

Vitaliano, P., Maieiro, R., Russo, I., Katon, W., \& Hall, G. (1990). Coping profiles associated with psychiatric, physical health, work, and family problems. Health Psychology, 9(3), 348-376. $<$ http://dx.doi.org/10.1037/0278-6133.9.3.348>

Wagner, A., Aizenstein, H., Venkatraman, V. K., \& Kaye, W. H. (2007). Altered reward processing in women recovered from anorexia nervosa. The American Journal of Psychiatry, 164(12), 1842-1849. $<$ http://dx.doi.org/10.1176/appi.ajp.2007.07040575>

Weaver, K., Wuest, J., \& Ciliska, D. (2005). Understanding women's journey of recovering from anorexia nervosa. Qualitative Health Research, 15(2), 188-206. <http://dx.doi.org/10.1177/1049732304270819>

Wenger, E. (2002). Communities of practice and social learning systems. In F. Reeve, M. Carrewright, \& R. Edwards (Eds.), Supporting lifelong learning 2: organizing learning (pp. 160-179). London \& New York: RoutledgeFalmer.

Whittemore, R., Chase, S., \& Mandle, C. L. (2001). Validity in qualitative research. Qualitative Health Research, 11(4), 522-537. <http://dx.doi.org/10.1177/104973201129119299>

Wuest, J. (2011). Are we there yet? Positioning qualitative research differently. Qualitative Health Research, 21(7), 875-883. <http://dx.doi.org/10.1177/1049732311401424>

Yager, J., Devlin, M. J., Halmi, K. A....\& Zerbe K. J. (2005). Eating disorders. Focus, 3(4), 503-510.

Zandian, M., Ioakimidis, I., Bergh, C., \& Södersten, P. (2007). Cause and treatment of Anorexia Nervosa. Physiology \& Behavior, 92(1-2), 283-290. <http://dx.doi.org/10.1016/j.physbeh.2007.05.052> 
Savukoski, M., Määttä, K., \& Uusiautti, S. 